\title{
Laboratory Measurement of Displacement on Shallow Foundation in Uniform Sand using Particle Image Velocimetry Technique
}

\author{
Siti Noor Linda Taib ${ }^{a^{*}}$, Lau See Hung ${ }^{a}$, Prabir Kumar Kolay ${ }^{b}$ \\ aniversiti Malaysia Sarawak, Faculty of Engineering, 94300 Kota Samarahan, Sarawak, Malaysia \\ ${ }^{b}$ Southern Illinois University, Carbondale, U.S.A
}

*Corresponding author: tlinda@feng.unimas.my

\section{Article history}

Received :1 November 2012

Received in revised form :15 January

2013

Accepted :15 March 2013

Graphical abstract

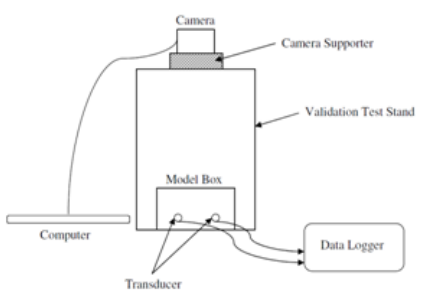

\begin{abstract}
Particle Image Velocimetry (PIV) is one of the non-intrusive techniques recently being utilized for measuring soil displacement in geotechnical engineering. The work discussed in this paper focuses on the application of an image processing tool known as MatPIV, a freeware readily available to the general users. The test programmes involved measurement and visualization of the behavior of displaced soil under various type of loadings and sizes of the foundation plate. Prior to testing, validation test was performed to study on the validity of measurements produced by MatPIV by comparing its measurements with the actual. Boundary analysis was also performed to justify on the configuration chosen for the model box used in both validation and experimental set-ups. In addition, a set of 70 displacement data was also studied in the validation test and a further statistical analysis on the data showed an acceptable accuracy of 98.8\% for the MatPIV analysis when compared to the actual measured displacement. Hence, further test programmes which consisted of various soil-structure interaction conditions were performed. This comprehensive analysis showed that the diameter of loading rods and the sizes of foundation plate do affect the behavior of soil displacement under centric structural loading and was shown successfully via MatPIV.
\end{abstract}

Keywords: Foundation; MatPIV; particle image velocimetry (PIV); soil displacement; soil-structure interaction

\begin{abstract}
Abstrak
Kaedah Particle Image Velocimetry (PIV) adalah salah satu teknik pengukuran tanpa terobosan yang barubaru ini diaplikasi bagi mengukur pergerakan tanah di dalam bidang kejuruteraan geoteknikal. Kertas penyelidikan ini mengfokus kepada penggunaan teknik memproses imej dan gerakan iaitu MatPIV, aplikasi percuma di laman sesawang yang boleh diperolehi umum. Penyelidikan ini melibatkan pengukuran dan observasi ke atas sifat-sifat pergerakan tanah disebabkan oleh bebanan dan saiz plat tapak yang berbeza. Sebelum ujian dilaksanakan, ujian validasi dijalani dahulu bagi mengukuhkan bacaan yang diperolehi melalui MatPIV dengan membandingkannya kepada bacaan sebenar. Analisa ke atas impak batas kotak model juga dijalankan bagi mengesahkan dimensi yang sesuai untuk kotak model yang akan digunakan. Selain dari itu, sebanyak 70 data bacaan pergerakan tanah juga diukur melalui MatPIV dan bacaan sebenar dan analisa statistik menunjukkan yang data-data tersebut mencapai tahap ketepatan sebanyak $98.8 \%$. Oleh itu, dengan tahap ketepatan yang tinggi ini, ujian selanjutnya yang melibatkan pelbagai kondisi interaksi antara tanah dan struktur dapat dilaksanakan dengan yakin. Analisa yang komprehensif ini memberi rumusan berikut di mana diameter rod beban dan saiz plat tapak memberi kesan ke atas sifat-sifat pergerakan tanah yang dibebankan secara memusat dan ini dapat ditunjukkan dengan jayanya melalui MatPIV.
\end{abstract}

Kata kunci: Tapak; MatPIV; particle image velocimetry (PIV); pergerakan tanah; interaksi tanah dan struktur

() 2013 Penerbit UTM Press. All rights reserved.

\subsection{INTRODUCTION}

Particle image velocimetry (PIV) has been widely used in fluids analysis for measuring the instantaneous flow of velocity field within a short time interval [1]. The vast development of photography technology triggers the growing interest on PIV. Thus, significant amount of studies in developing the theories and applications of PIV in fluid and particle analysis had been 